OPEN ACCESS

Edited by:

Joemer Maravilla,

University of Queensland, Australia

Reviewed by:

Nihar Ranjan Mishra,

Veer Surendra Sai Medical College

and Hospital, India

Delia Boccia,

University of London, United Kingdom

${ }^{*}$ Correspondence:

Chukwuemeka Onwuchekwa

emyonwuchekwa@gmail.com

tThese authors have contributed equally to this work and share senior authorship

Specialty section:

This article was submitted to Children and Health,

a section of the journal

Frontiers in Public Health

Received: 21 January 2021 Accepted: 14 June 2021

Published: 14 July 2021

Citation:

Onwuchekwa C, Verdonck K and Marchal B (2021) Systematic Review on the Impact of Conditional Cash Transfers on Child Health Service Utilisation and Child Health in Sub-Saharan Africa.

Front. Public Health 9:643621. doi: 10.3389/fpubh.2021.643621

\section{Systematic Review on the Impact of Conditional Cash Transfers on Child Health Service Utilisation and Child Health in Sub-Saharan Africa}

\author{
Chukwuemeka Onwuchekwa*, Kristien Verdonck ${ }^{\dagger}$ and Bruno Marchal ${ }^{\dagger}$ \\ Department of Public Health, Institute of Tropical Medicine, Antwerp, Belgium
}

Background: Conditional cash transfers (CCTs) are interventions which provide assistance in the form of cash to specific vulnerable groups on the condition that they meet pre-defined requirements. The impact of conditional cash transfers on children's access to health services and on their overall health has not been established in sub-Saharan Africa.

Method: We conducted a systematic review aimed at summarising the available information on the impact of conditional cash transfers on health service utilisation and child health in sub-Saharan Africa. We searched databases for peer-reviewed articles, websites of organisations involved in implementing conditional cash transfer programmes, and Google scholar to identify grey literature. Records were selected based on predefined eligibility criteria which were drawn from a programme impact framework. Records were eligible if one of the following outcomes was evaluated: health services utilisation, immunisation coverage, growth monitoring, anthropometry, illness reported, and mortality. Other records which reported on important intermediate outcomes or described mechanisms significantly contributing to impact were also included in the review. Data items were extracted from eligible records into an extraction form based on predefined data items. Study quality indicators were also extracted into a quality assessment form.

Results: Thematic narrative synthesis was conducted using data from nine included records. The review included five cluster randomised evaluations, one quasi-experimental clustered study, one randomised trial at the individual level, one mixed-method study and one purely qualitative study. There was insufficient evidence of an impact of conditional cash transfers on health service utilisation. There was also not enough evidence of an impact on nutritional status. No impact was observed on health status based on illness reports, nor on immunisation rates. None of the included records evaluated the impact on childhood mortality.

Conclusions: The findings of this review suggest that a positive impact may be observed in health service utilisation and nutrition, however, this may not translate 
into improved child health. Further research is needed to understand the mechanisms and pathways by which these interventions work, explore the effect of contextual factors on their impact, and assess their cost implication especially within resource-constrained settings.

Keywords: conditional cash transfer, child, health service utilisation, health status, sub-Saharan Africa

\section{INTRODUCTION}

Cash transfers are defined as the provision of assistance in the form of cash with the objective of increasing the household's real income (1). Conditional cash transfers (CCTs) provide monetary transfers to targeted populations (usually poor, vulnerable and underserved persons) as long as they adhere to specific programme requirements or conditions-for example children attend regular clinics and receive immunisations, or pregnant women attend regular antenatal clinics and deliver in a health facility $(1,2)$. Cash transfers are aimed at relieving some of the financial constraints poor households face in accessing essential services like health care.

Since their introduction in Latin America in the 1990s, several evaluations have been conducted to assess the impact of CCTs on health service utilisation and health. Much of the evidence on the impact of CCTs comes from earlier programs in Latin America (1), the Caribbean (3) and parts of Asia $(4,5)$. These early impact evaluations suggest that CCTs, may have a positive impact on the diet of children from poor households and improve their nutritional status $(2,5-10)$, on attendance at routine clinical visits $(7,9,11-14)$, on the uptake of routine childhood immunisation $(4,9,11,13)$, and, in the long term, on child health $(7,15)$. However, these findings have not been consistent across studies, and some positive impacts were not sustained after longer periods of programme implementation $(9,16,17)$. Moreover, the effect of CCTs on child health and health service utilisation has not been established in sub-Saharan Africa where access to services is often inadequate and child health indicators remain poor.

This review sought to critically assess and summarise the available information on the impact of conditional cash transfers (CCTs) on child health and health service utilisation in subSaharan Africa. Specifically, we aim to summarise the evidence on the impact of CCT on routine health visits, uptake of immunisation services, child nutrition state and frequency of reported illness.

\section{METHODOLOGY}

\section{Study Design}

This is a review of published literature, programme reports and working papers detailing the impact of conditional cash transfers on child health and health service utilisation in subSaharan Africa. We started with a programme impact pathway as described by Leroy et al. (2), with elements from the work of de Groot et al. (18), to explore the pathways by which CCTs may impact on child health and health service utilisation (Supplementary Figure 1). Wherever possible, we adhered to the Preferred Reporting Items for Systematic reviews and MetaAnalysis (PRISMA) and the Systematic reviews Without Metaanalysis (SWiM) guidelines for reporting systematic reviews $(19,20)$. The research methods, including the search strategy, eligibility criteria and a preliminary plan for analysis and synthesis, were developed in advance of data extraction.

\section{Eligibility Criteria}

The SPICE framework (settings, perspective, intervention, comparison and evaluation) was used to formulate the research question (21). The research question is further detailed in Table 1.

We identified records of studies on the impact of CCTs from any country within sub-Saharan Africa. Records of studies on unconditional cash transfers and in-kind transfers were excluded. We included studies reporting on the impact of CCT intervention on an indicator of health access or utilisation (for instance attendance at routine clinics or immunisation uptake), or an indicator of health or nutrition (for instance frequency of reported illness or anthropometric measurements) in children who are under 5 years of age.

For a study to be eligible, it had to include a formal comparison between beneficiaries and non-beneficiaries, using either a contemporary or a historical comparison group. We included primary studies with the following designs: clusterrandomised studies, randomised-controlled trials, before-andafter studies and interrupted time-series designs. No time or language restrictions were put in place.

\section{Information Sources}

Records were identified following a systematic search of PubMed, EBSCO e-journal, EBSCO global health and African Index Medicus (AIM) using the search strategy detailed in Supplementary Table 1 . The first database search was conducted on 29 February 2020 (PubMed) and the last search on 13 March 2020 (EBSCO e-journal). In addition, we searched the websites of the World Bank (https://openknowledge.worldbank.org) and the Institute for Fiscal Studies (https://www.ifs.org.uk) for relevant titles. Finally, we searched Google scholar for reports that may have been missed by previous searches.

\section{Search Strategy}

The search strategy combined the following key themes of the research question:

i. Conditional cash transfers

ii. Children under-five

iii. Sub-Saharan Africa 
The search strategy was initially developed for PubMed and subsequently adapted to other indexed databases. The complete strategy for each search is included as Supplementary Table 1.

\section{Study Selection}

The titles and abstract of records retrieved from the search were screened to identify potentially relevant records. For the records that were deemed eligible at this stage, the full-texts were obtained and screened. Records that met the eligibility criteria after the full-text screening were then included in the review. We also conducted a manual search of the reference lists of included records to identify additional records for inclusion into the review.

\section{Data Collection Process and Data Items}

Data extraction was conducted using a pre-piloted extraction form developed in Excel containing relevant data items (Supplementary Table 2). The following specific data items were collected: first author name and affiliation, year of publication, article source; programme name, country, rural or urban setting, year intervention initiated, situation under which intervention was conducted (stable or unstable), cash transfer amount in USD, frequency of transfers, direct recipient, any concurrent supply-side interventions, and description of transfer conditions, baseline year, evaluation year, population evaluated, evaluation design, type of analysis, data collection technique, outcomes evaluated, and findings.

\section{Quality Assessment of Individual Studies}

We developed a quality assessment instrument for this review, designed to capture the specific quality dimensions of impact studies (Supplementary Table 2). Our assessment instrument borrows elements from The National Heart, Lung and Blood Institute quality assessment tool for randomised interventions, and the Methodological index for non-randomised studies (MINORS) instrument (22). This assessment instrument was not designed to assign a "quality score" to studies, but to provide an overview of the quality assessment of each study. The elements and questions in the instrument are presented in Box 1 below. We also used the assessment tool developed by Walsh and Downe, to appraise the qualitative studies (23).

\section{Data Presentation and Synthesis}

Because context, study design, and outcome assessment varied across the included studies, we conducted a narrative synthesis and did not attempt to quantitatively pool the findings. We first describe the general characteristics and the quality of the included studies. Next, we present the key findings focusing on both intermediate and final outcomes.

\section{Ethical Considerations}

The review did not directly involve human subjects and ethical concerns are therefore minimal. However, during the review process, due consideration was given to the ethical conduct of included studies (24).
TABLE 1 | Details of review question using the SPICE framework.

\begin{tabular}{|c|c|}
\hline Element & Description \\
\hline Setting & $\begin{array}{l}\text { Any of the countries within sub-Saharan Africa } \\
\text { where a conditional cash transfer intervention has } \\
\text { been implemented }\end{array}$ \\
\hline Perspective & Children $<5$ years of age \\
\hline Intervention & $\begin{array}{l}\text { Any intervention where cash is provided to individua } \\
\text { or household on the condition that they fulfil specific } \\
\text { health related conditions }\end{array}$ \\
\hline Comparison & $\begin{array}{l}\text { Comparison groups who benefit from CCT } \\
\text { intervention and those who do not, populations } \\
\text { before and after the CCT intervention }\end{array}$ \\
\hline Evaluation & $\begin{array}{l}\text { Impact on use of preventive and curative health } \\
\text { services, nutritional status and health status }\end{array}$ \\
\hline \multicolumn{2}{|c|}{ BOX 1 | Elements of the quality assessment instrument used in the review. } \\
\hline Element & Question asked \\
\hline Study method & $\begin{array}{l}\text { Was the study method appropriate to the } \\
\text { question the study set out to answer? }\end{array}$ \\
\hline Sample size & $\begin{array}{l}\text { Was the sample size measured } \\
\text { prospectively? } \\
\text { Was sample size justified? }\end{array}$ \\
\hline Outcome assessment & $\begin{array}{l}\text { Were outcome assessors blinded to the } \\
\text { allocation of the respondent? }\end{array}$ \\
\hline Randomisation & $\begin{array}{l}\text { Did any event occur during conduct of the } \\
\text { study that could have compromised } \\
\text { randomisation? (include contamination) }\end{array}$ \\
\hline Outcome measurement & $\begin{array}{l}\text { Were all outcomes measured in a valid or } \\
\text { objective way? }\end{array}$ \\
\hline Analysis & $\begin{array}{l}\text { Was the analysis appropriate? (include } \\
\text { control for confounding, appropriate } \\
\text { consideration for time trend) }\end{array}$ \\
\hline Adequate comparison & Were the groups comparable at baseline? \\
\hline Attrition or loss to follow-up & $\begin{array}{l}\text { Was loss to follow-up or attrition } \\
\text { significant? (more than 5\%) } \\
\text { Was loss to follow-up or attrition different } \\
\text { between groups? }\end{array}$ \\
\hline Conflict of interest & $\begin{array}{l}\text { Was there potential conflict of interest } \\
\text { between authors or sponsors and the } \\
\text { CCT implementing institution? }\end{array}$ \\
\hline
\end{tabular}

\section{RESULTS}

\section{Summary of Eligible Records}

The search of indexed databases produced 123 records, while other sources produced 429 records. Nine of these records were included, describing eight conditional cash transfer programmes in seven sub-Sahara African countries implemented between 2008 and 2016. The record selection process is detailed in a PRISMA diagram (Figure 1).

\section{Study Characteristics \\ Description of Programmes}

Table 2 describes the CCT programmes included in the review. Six programmes were pilot projects, one was a research project and one was an emergency programme (addressing a drought). 


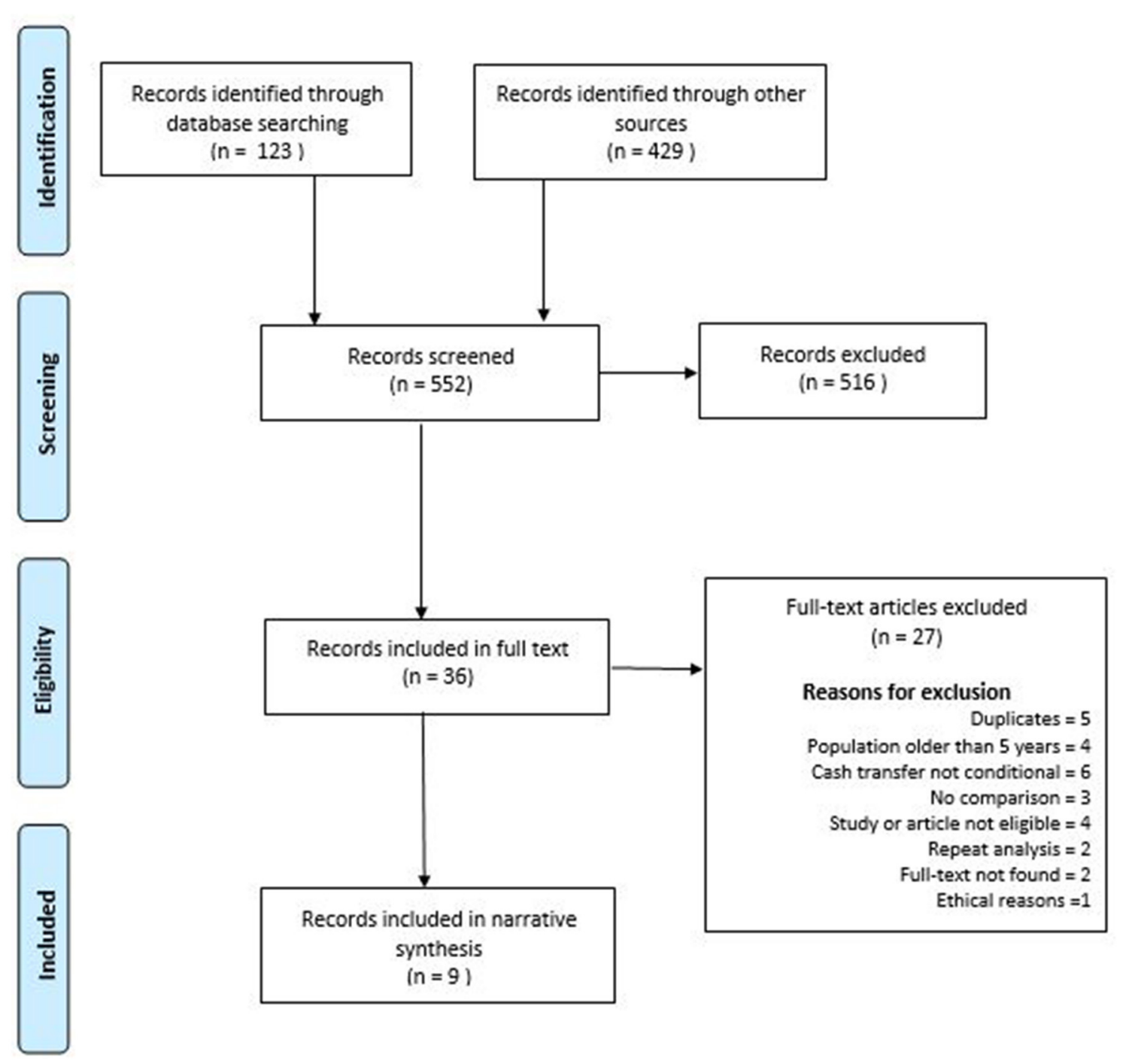

FIGURE 1 | PRISMA flow chart showing the record selection process.

All but one of the programmes were conducted in rural settings, which were considered poor or underserved (31).

The amount of cash given to beneficiaries varied between programmes (see Table 2 ), and was mostly received by adult women in the households.

\section{Description of the Evaluation Designs}

Seven of the included studies focused on the quantitative impact of the CCT programme, while two studies were of a qualitative nature.

\section{Quantitative Evaluations}

As detailed in Table 2, the study methodology of the quantitative studies varied considerably. Six were clustered studies with or without random assignment, and one was a randomised trial at the individual level. All clustered studies conducted baseline and follow-up surveys, with the follow-up surveys typically conducted 1-2 years after initiation of the CCT.

\section{Qualitative Evaluations}

The two qualitative studies included in this review used interviews with mothers or caregivers of children from CCT recipient households. Respondents were selected purposively in both evaluations. Data collection was by individual and/or group interviews using a semi-structured format; in both studies, only beneficiaries were interviewed. Respondent triangulation was done in both evaluations.

\section{Outcomes Measured in Evaluations}

The studies included in this review reported on the following quantitative outcomes: immunisation rates $(n=3)$, health centre attendance $(n=3)$, illness or ill days preceding the survey $(n=3)$, 
nutritional status [ $n=3$, measured as weight, height, height-forage $\mathrm{z}$-score (HAZ), weight-for-age $\mathrm{z}$-score (WAZ), weight-forheight $\mathrm{z}$-score (WHZ), and mid-arm circumference (MUAC)], dietary intake $(n=1$, measured as frequency and diversity from 24-h recall from care-givers, mothers' knowledge on health and nutrition $(n=1)$, and early infant intervention in HIV/AIDS $(n=1)$.

\section{Quality Assessment of Individual Studies Quantitative Evaluations}

Overall, all included quantitative studies had at least one significant quality concern. A key area of concern in many included studies was the absence of effective observer blinding. Potential conflict of interest was also identified in all included studies (Supplementary Table 2).

\section{Qualitative Evaluations}

The guidance by Walsh and Downe allows appraising qualitative studies based mainly on sample size determination, triangulation and reflexivity (33). Details of the quality assessment are presented in Supplementary Table 2. Overall, we identified gaps in the reporting of the justification on the sample-size and the potential influence of reflexivity in one of the two qualitative studies (32).

\section{Summary Findings of Individual Studies}

The key findings of the included studies are summarised in Table 3 below.

\section{Synthesis of Findings \\ Effect on Dietary Intake}

Two studies reported on the impact of a CCT programme on household dietary intake. The emergency CCT programme in Niger and the Tanzania Social Action Fund (TASAF) programme in Tanzania both showed an increase in consumption of most food groups among beneficiaries, most importantly in the consumption of proteins $(25,34)$.

\section{Effect on Nutritional Outcomes}

Three studies reported on nutritional outcomes, with only one showing a positive effect in CCT beneficiaries (Table 4). In the emergency CCT intervention in Niger, beneficiaries gained significantly more weight than controls (25).

\section{Effect on Health Clinic Visits}

Among the three studies that evaluated the impact of CCT on health facility utilisation, two reported a positive effect among beneficiaries (Table 5). Children who benefited from the TASAF programme in Tanzania had significantly more routine clinic visits than controls, although this effect was not significant after 2.5 years of the programme (30).

\section{Effect on Immunisation Rates}

The three studies that assessed the impact of CCTs on the proportion of children vaccinated showed no difference between the CCT beneficiaries and the control groups (Table 6). Beneficiaries of the Manicaland HIV/STD prevention project cash transfers experienced a higher increase in immunisation rates from baseline among beneficiaries (23). Beneficiaries of the SNACK-CNA and SURE-P cash transfers were not more likely to receive immunisations than those who did not $(26,28)$.

\section{Effect on Utilisation of Specific Health Interventions}

The randomised trial by Yotebieng et al. reported no significant difference in proportion of children receiving early infant diagnosis (EID) for HIV (31).

\section{Effect on Illness Report}

None of the studies reported a significant difference in the frequency of illness reported between CCT recipients and control groups (Table 7). None of the included studies reported on specific childhood illnesses, and all based their measurement on caregivers recall $(25,26,30)$.

\section{Thematic Synthesis Exploring Underlying Mechanisms of CCT Impact on Child Health The Incentive Value of the Cash Transfers}

The SNACK-CNA pilot project reported that overall, the cash transfer was not considered to significantly influence the decision to visit a health facility. Furthermore, the amount provided in transfers was thought to be insufficient to cover the cost of seeking health care, thereby constraining the incentive value of the transfer (27).

\section{How Households Used the Extra Income From the CCT}

Responding caregivers in the LEAP pilot in Ghana indicated that food purchase was one of the main uses of the cash benefits. Respondents suggested that the cash transfer increased household income and improved dietary intake. The cash transfers were also used to access health services, as commented by respondents (32). Mothers in the SNACK-CNA pilot likewise reported using the extra income to buy food (and clothes) and to cover health expenses $(26,27)$.

\section{Additional Synthesis by Subgroup Effect of CCT by Level of Household Poverty}

The study of Evans et al. (28) and of Akresh et al. (35) report that included subgroup analysis by household poverty level showed no association between the level of household poverty and the effect of CCT on health service utilisation.

\section{Effect of CCT by Child Sex}

Akresh et al. report a significantly higher number of routine clinical visits per year among female beneficiaries that was not demonstrated in male counterparts (29). Evans et al., however, showed a significantly lower number of yearly clinic visits among female children in the CCTs group; among male children, the yearly clinic visit did not differ significantly between the groups (30).

\section{Risk of Bias Across Studies}

We did not formally assess the risk of publication bias with a funnel plot due to the small number and the diversity of study designs among the included studies. It was our assessment that a funnel plot may indeed produce misleading results due to this diversity between methodology in the included records (35). 
TABLE 2 | Description of programmes evaluated in the review.

\begin{tabular}{|c|c|c|c|c|c|c|c|c|c|}
\hline CCT programme & References & $\begin{array}{l}\text { Country and } \\
\text { setting }\end{array}$ & Situation, target & Cash transfer schedule & Related conditions ${ }^{*}$ & $\begin{array}{l}\text { Evaluation } \\
\text { design }\end{array}$ & Type of analysis & $\begin{array}{l}\text { Follow-up } \\
\text { period }^{\star \star}\end{array}$ & $\begin{array}{l}\text { Organisation(s) } \\
\text { implementing } \\
\text { CCT }\end{array}$ \\
\hline $\begin{array}{l}\text { Manicaland } \\
\text { HIV/STD } \\
\text { prevention project }\end{array}$ & (23) & $\begin{array}{l}\text { Zimbabwe } \\
\text { Rural }\end{array}$ & $\begin{array}{l}\text { Pilot, Vulnerable household } \\
\text { in selected communities }\end{array}$ & $\begin{array}{l}\$ 18 \text { for household, } \$ 4 \text { per } \\
\text { child to max } 3 \text { children } \\
\text { bimonthly }\end{array}$ & $\begin{array}{l}\text { Up-to-date immunisation in } \\
\text { children under } 5 \text { years } \\
\text { Growth monitoring twice a } \\
\text { year } \\
\text { Parenting skill classes for } \\
\text { family representative. }\end{array}$ & $\begin{array}{l}\text { Matched cluster } \\
\text { randomised } \\
\text { experiment }\end{array}$ & $\begin{array}{l}\text { Difference-in- } \\
\text { Difference }\end{array}$ & 12 months & $\begin{array}{l}\text { Wellcome trust, } \\
\text { World Bank, } \\
\text { United Nations } \\
\text { children's fund }\end{array}$ \\
\hline $\begin{array}{l}\text { Concern } \\
\text { worldwide CCT } \\
\text { programme }\end{array}$ & (25) & Niger, Rural & $\begin{array}{l}\text { Emergency famine, } \\
\text { Vulnerable households }\end{array}$ & $\begin{array}{l}\$ 250 \text { over } 3 \text { months to } \\
\text { households }\end{array}$ & $\begin{array}{l}\text { Attendance of health and } \\
\text { nutrition classes by mothers }\end{array}$ & $\begin{array}{l}\text { Quasi- } \\
\text { experimental }\end{array}$ & $\begin{array}{l}\text { Difference-in- } \\
\text { Difference }\end{array}$ & 3-6 months & $\begin{array}{l}\text { Concern } \\
\text { worldwide }\end{array}$ \\
\hline \multirow[t]{2}{*}{$\begin{array}{l}\text { SNACK-CNA } \\
\text { programme }^{\ddagger}\end{array}$} & (26) & Mali, Rural & $\begin{array}{l}\text { Pilot, Vulnerable households } \\
\text { in selected communities }\end{array}$ & $\begin{array}{l}\text { Approximately } \$ 96 \text { over } \\
\text { pregnancy up to } 24 \text { months } \\
\text { (paid per condition } \\
\text { completed } \$ 4 \text { vaccination, } \\
\$ 3 \text { /Growth monitor) }\end{array}$ & $\begin{array}{l}\text { Vaccination. Monthly growth } \\
\text { monitoring visits }\end{array}$ & $\begin{array}{l}\text { Cluster } \\
\text { randomised } \\
\text { experiment }\end{array}$ & $\begin{array}{l}\text { Regression } \\
\text { analysis }\end{array}$ & 24 months & $\begin{array}{l}\text { Global affairs } \\
\text { Canada, World } \\
\text { Food Programme } \\
\text { and United } \\
\text { Nations children's } \\
\text { Funds }\end{array}$ \\
\hline & (27) & & & & & Mixed methods & $\begin{array}{l}\text { Descriptive } \\
\text { Thematic analysis }\end{array}$ & $\begin{array}{l}\text { Approximately } 12 \\
\text { months }\end{array}$ & \\
\hline SURE-P MCH & (28) & Nigeria, Rural & $\begin{array}{l}\text { Pilot, Selected health } \\
\text { facilities }\end{array}$ & $\begin{array}{l}\$ 30 \text { over pregnancy up to } 6 \\
\text { weeks post-natal ( } \$ 6 \text { at first } \\
\text { immunisation) to mothers }\end{array}$ & OPV-1 vaccination & $\begin{array}{l}\text { Quasi- } \\
\text { experimental }\end{array}$ & Time-series & 12 months & $\begin{array}{l}\text { SURE-P MCH, } \\
\text { children } \\
\text { investment fund } \\
\text { foundation, } \\
\text { Mckinsey \& } \\
\text { Company }\end{array}$ \\
\hline Nahourio CTPP & (29) & $\begin{array}{l}\text { Burkina Faso, } \\
\text { Rural }\end{array}$ & $\begin{array}{l}\text { Pilot, Vulnerable households } \\
\text { in selected communities }\end{array}$ & $\begin{array}{l}\$ 9.64 \text { per child per year to } \\
\text { households }\end{array}$ & $\begin{array}{l}\text { Quarterly visits to health } \\
\text { facility for growth monitoring }\end{array}$ & $\begin{array}{l}\text { Cluster } \\
\text { randomised } \\
\text { experiment }\end{array}$ & $\begin{array}{l}\text { Regression } \\
\text { analysis }\end{array}$ & 21 months & World Bank \\
\hline TASAF & (30) & $\begin{array}{l}\text { Tanzania, } \\
\text { Rural }\end{array}$ & $\begin{array}{l}\text { Pilot, Vulnerable households } \\
\text { in selected communities }\end{array}$ & $\begin{array}{l}\$ 14.5(\$ 12-36) \text { bimonthly to } \\
\text { households }\end{array}$ & $\begin{array}{l}\text { Vaccination. Six visits to } \\
\text { health facility for weight } \\
\text { monitoring }\end{array}$ & $\begin{array}{l}\text { Cluster } \\
\text { randomised } \\
\text { experiment }\end{array}$ & $\begin{array}{l}\text { Regression } \\
\text { analysis }\end{array}$ & 22 months & World Bank \\
\hline Not applicable $\ddagger$ & (31) & $\begin{array}{l}\text { Democratic } \\
\text { Republic of } \\
\text { Congo, Urban }\end{array}$ & Research & $\begin{array}{l}\text { Maximum } \$ 45 \text { from } \\
\text { pregnancy to } 6 \text { weeks } \\
\text { post-natal \# }\end{array}$ & $\begin{array}{l}\text { HIV early infant diagnosis at } \\
6 \text { weeks }\end{array}$ & $\begin{array}{l}\text { Individual } \\
\text { randomised } \\
\text { controlled } \\
\text { experiment }\end{array}$ & $\begin{array}{l}\text { Regression } \\
\text { analysis } \\
\text { (Intention-to-treat) }\end{array}$ & 12 months & $\begin{array}{l}\text { PEPFAR and the } \\
\text { NIHCD }\end{array}$ \\
\hline LEAP & (32) & Ghana, Rural & Pilot, Vulnerable households & $\begin{array}{l}\$ 21-39 \text { per month to } \\
\text { households (plus health } \\
\text { insurance) }\end{array}$ & Health check-ups & $\begin{array}{l}\text { Qualitative } \\
\text { methods }\end{array}$ & Thematic analysis & $\begin{array}{l}\text { Approximately } 24 \\
\text { months }\end{array}$ & $\begin{array}{l}\text { Ghana Ministry of } \\
\text { Gender, Children } \\
\text { and Social } \\
\text { Protection }\end{array}$ \\
\hline
\end{tabular}

SNACK-CNA, Santé Nutritionnelle à Assise Communautaire à Kayes-cash for nutritional awareness; HIV, Human immunodeficiency virus; STD, sexually transmitted diseases; SURE-P MCH, Subsidy Reinvestment and Empowerment Programme Maternal and Child Health Project; CTTP, Cash Transfers Pilot Project; TASAF, Tanzania Social Action Fund; LEAP, Livelihood Empowerment Against Poverty; OPV-1, Oral Polio Vaccine first dose; PEPFAR, The President's

Emergency Plan for AIDS Relief; NIHCD, National Institute of Health and Child Development.

${ }^{*}$ Describes conditions related to utilisation of child services.

**Period between initiation of intervention and final evaluation.

${ }^{\ddagger}$ CCTs initiated during pregnancy.

\#CCTs targeting HIV prevention of mother-to-child services. 
TABLE 3 | Summary of finding of evaluations included in the review.

\begin{tabular}{|c|c|c|c|c|}
\hline References & Programme & Study design & Age & Key findings \\
\hline Robertson et al. (23) & $\begin{array}{l}\text { Manicaland HIV/STD } \\
\text { prevention project, } \\
\text { Zimbabwe }\end{array}$ & $\begin{array}{l}\text { Matched cluster } \\
\text { randomised study }\end{array}$ & 0-59 months & $\begin{array}{l}\text { No significant difference in up-to-date } \\
\text { immunisation records }\end{array}$ \\
\hline \multirow[t]{3}{*}{ Bliss et al. (25) } & $\begin{array}{l}\text { concern worldwide CCT } \\
\text { programme, Niger }\end{array}$ & Quasi-Experimental design & $6-24$ months & $\begin{array}{l}\text { No difference in reported illness in } \\
\text { preceding } 15 \text { days }\end{array}$ \\
\hline & & & & $\begin{array}{l}\text { Significant difference in anthropometry } \\
\text { (Weight, WHZ and MUAC) }\end{array}$ \\
\hline & & & & $\begin{array}{l}\text { Significant increase in meal frequency and } \\
\text { diversity in preceding } 24 \mathrm{~h}\end{array}$ \\
\hline \multirow[t]{5}{*}{ Adubra et al. (26) } & SNACK-CNA, Mali & Cluster randomised study & 12-42 months & $\begin{array}{l}\text { No observed difference in immunisation } \\
\text { rates }\end{array}$ \\
\hline & & & & $\begin{array}{l}\text { No difference in number of routine growth } \\
\text { monitoring visits in past year }\end{array}$ \\
\hline & & & & $\begin{array}{l}\text { No difference in illness reports in } \\
\text { preceding } 15 \text { days }\end{array}$ \\
\hline & & & & $\begin{array}{l}\text { No difference in meal frequency and } \\
\text { diversity in preceding } 24 \mathrm{~h}\end{array}$ \\
\hline & & & & No difference in HAZ \\
\hline Okoli et al. (28) & SURE-P MCH, Nigeria & Quasi-experimental design & $<6$ weeks & $\begin{array}{l}\text { No difference in OPV rate in intervention } \\
\text { and control sites }\end{array}$ \\
\hline Akresh et al. (29) & $\begin{array}{l}\text { Nahourio CTPP, Burkina } \\
\text { Faso }\end{array}$ & $\begin{array}{l}\text { Factorial cluster randomised } \\
\text { study }\end{array}$ & 0-59 months & $\begin{array}{l}\text { More routine clinic visit per year in CCT } \\
\text { recipients }\end{array}$ \\
\hline \multirow[t]{4}{*}{ Evans and Hausladen (30) } & TASAF, Tanzania & Cluster randomised study & 0-23 months & $\begin{array}{l}\text { No difference in number of health facility } \\
\text { visits at midline }\end{array}$ \\
\hline & & & 0-59 months & $\begin{array}{l}\text { No difference in anthropometry (Height, } \\
\text { Weight, HAZ, WAZ, WHZ, MUAC). }\end{array}$ \\
\hline & & & 0-59 months & $\begin{array}{l}\text { No significant difference in reported illness } \\
\text { in preceding } 4 \text { weeks. }\end{array}$ \\
\hline & & & Household level & $\begin{array}{l}\text { Increase in dietary intake. } \\
\text { No increase in consumption of } \\
\text { harmful commodities }\end{array}$ \\
\hline Yotebieng et al. (31) & Not applicable & $\begin{array}{l}\text { Individual randomised } \\
\text { control trial }\end{array}$ & $<6$ weeks & $\begin{array}{l}\text { No significant difference in proportion of } \\
\text { children receiving early infant diagnosis for } \\
\text { HIV }\end{array}$ \\
\hline
\end{tabular}

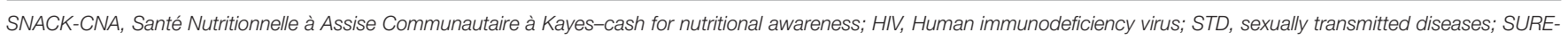

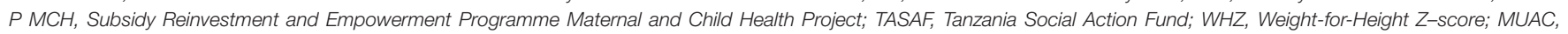
mid-upper arm circumference; HAZ, Height-for-Age Z-score; WAZ, Weight-for-Age Z-Score; CTTP, Cash Transfers Pilot Project.

\section{DISCUSSION}

\section{Summary of Findings}

This review aimed to investigate the effect of CCT on utilisation of health services, and on health status. Based on the programme impact theory, we hypothesised that CCT will have a positive impact on child health by improving utilisation of health services and improved nutrition. An important coincidental finding from this review is the paucity of impact studies in this area, and the lack of uniformity in how CCTs are implemented and evaluated. Overall, this review found that there is no evidence that demonstrates a positive effect of CCT on the illness among children in sub-Saharan Africa. The evidence of improved health service use and nutritional status is inconsistent between studies. Despite indications that the extra household income from CCT is mostly used for improving the household diet $(25-27,34)$, this has not consistently translated into better nutrition for children in SSA. Interestingly, a positive nutritional impact was observed when cash transfers were given to households experiencing sudden and profound food insecurity, as shown in the emergency programme in Niger (25). The evidence of an impact on routine clinic visits was inconsistent across included studies. Furthermore, in one study, an initial observed impact was not sustained on the long term (30). No positive effect on immunisation uptake was demonstrated across all three studies exploring this outcome $(23,26,28)$. Overall, we show that CCTs can help remove some of the financial barriers to health service and improved nutrition, but this is not a consistent observation in the studies we reviewed.

While our review suggests that CCT can improve household and childhood diet quality by augmenting household income, there is inconsistent evidence for an association between CCT and improved childhood nutrition based on anthropometric 
TABLE 4 | Effect of CCT on anthropometric measures.

\begin{tabular}{|c|c|c|c|c|c|c|}
\hline References & Study Design & Age (months) & Outcome & Baseline (CCT) & $\begin{array}{l}\text { Baseline } \\
\text { (control) }\end{array}$ & Effect size \\
\hline \multirow[t]{3}{*}{ Bliss et al. (25) } & $\begin{array}{l}\text { Quasi- } \\
\text { Experimental } \\
\text { design }\end{array}$ & $6-24$ & $\begin{array}{l}\text { Weight-mean } \\
\text { and sd }(\mathrm{kg})\end{array}$ & $7.89(1.00)$ & $8.24(1.00)$ & $1.35(p<0.001)^{a}$ \\
\hline & & & $\begin{array}{l}\text { WHZ-mean and } \\
\text { sd }\end{array}$ & $-1.5(1.1)$ & $-1.0(1.1)$ & $1.83(p<0.001)^{a}$ \\
\hline & & & $\begin{array}{l}\text { MUAC-mean } \\
\text { and sd (mm) }\end{array}$ & $137(8)$ & $139(9)$ & $7.0(p<0.001)^{a}$ \\
\hline \multirow[t]{2}{*}{ Adubra et al. (26) } & $\begin{array}{l}\text { Cluster } \\
\text { randomised } \\
\text { design }\end{array}$ & $12-42$ & $\begin{array}{l}\text { HAZ_-mean and } \\
\text { sd }\end{array}$ & $-1.57(1.23)$ & $-1.40(1.23)$ & $0.03(p=0.75)^{\mathrm{b}}$ \\
\hline & & & $\begin{array}{l}\text { Prevalence of } \\
\text { stunting (\%) }\end{array}$ & 35.6 & 29.5 & $0.87(p=0.32)^{c}$ \\
\hline \multirow[t]{3}{*}{$\begin{array}{l}\text { Evans and } \\
\text { Hausladen (30) }\end{array}$} & $\begin{array}{l}\text { Cluster } \\
\text { randomised } \\
\text { design }\end{array}$ & $0-59$ & $\begin{array}{l}\text { Height-Mean } \\
(\mathrm{cm})\end{array}$ & \multicolumn{2}{|c|}{87.31 (combined) } & $0.53(p>0.1)^{b}$ \\
\hline & & $0-59$ & $\begin{array}{l}\text { Weight-Mean } \\
(\mathrm{kg})\end{array}$ & \multicolumn{2}{|c|}{12.16 (combined) } & $0.16(p>0.1)^{b}$ \\
\hline & & $0-59$ & $\begin{array}{l}\text { MUAC-Mean } \\
(\mathrm{mm})\end{array}$ & \multicolumn{2}{|c|}{155.81 (combined) } & $1.42(p>0.1)^{b}$ \\
\hline
\end{tabular}

WHZ, Weight-for-Height Z-score; MUAC, mid-upper arm circumference; HAZ, Height-for-Age Z-score; cm, centimetre; kg, kilogrammes; mm, millimetres; sd, standard deviation. ${ }^{a}$ Difference-in-differences analysis; ${ }^{b}$ Linear regression analysis ( $\beta$ coefficient), ${ }^{C}$ Logistic regression analysis with adjusted odds ratio.

TABLE 5 | Effect of CCT on clinic visits.

\begin{tabular}{|c|c|c|c|c|c|c|}
\hline References & Study Design & Age (months) & Outcome & $\begin{array}{l}\text { Baseline } \\
\text { (CCT) }\end{array}$ & $\begin{array}{l}\text { Baseline } \\
\text { (control) }\end{array}$ & Effect size \\
\hline Akresh et al. (29) & $\begin{array}{l}\text { Factorial cluster randomised } \\
\text { design }\end{array}$ & $0-59$ & $\begin{array}{l}\text { Mean number of preventive } \\
\text { health visits in past year }\end{array}$ & \multicolumn{2}{|c|}{1.03} & $0.43(p \leq 0.001)^{\mathrm{a}}$ \\
\hline \multirow[t]{2}{*}{ Adubra et al. (26) } & Cluster randomised design & $12-42$ & $\begin{array}{l}\text { More than half routine visits } \\
\text { (\%) }\end{array}$ & 29.0 & 36.5 & $\begin{array}{l}3.07(95 \% \mathrm{Cl} 0.93 \text {, } \\
10.17)^{\mathrm{b}}\end{array}$ \\
\hline & & & $\begin{array}{l}\text { One or more routine visits } \\
(\%)\end{array}$ & 43.6 & 44.2 & $\begin{array}{l}1.36(95 \% \mathrm{Cl} 0.69 \\
2.70)^{\mathrm{b}}\end{array}$ \\
\hline $\begin{array}{l}\text { Evans and Hausladen } \\
\text { (30) }\end{array}$ & Cluster randomised design & $0-24$ & $\begin{array}{l}\text { Mean number of health } \\
\text { visits in past year }\end{array}$ & \multicolumn{2}{|c|}{9.2 (combined) } & $\begin{array}{l}-2.71(0.1>p> \\
0.05)^{\mathrm{a} \|}\end{array}$ \\
\hline
\end{tabular}

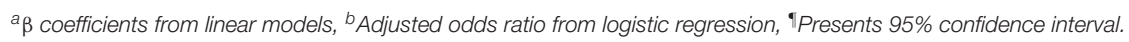

measurement. This is similar to findings from reviews of CCTs in Latin America, which showed a variable impact on anthropometry despite consistent evidence of improved diet among beneficiaries $(2,36)$. Some programmes showed a positive impact on anthropometry only in younger children (under 24 months). Other programmes like Programa de Asignación familia in Honduras and Familias en Acción in Colombia did not have a significant impact on anthropometric measures. Many of the programmes in Latin America that did show a positive impact included food fortification and health education as components. A health education component was only included in the emergency CCT programme in Niger (25). Inconsistent effects on health service utilisation have been reported in other reviews as well (1). The current body of evidence suggests that CCTs may only result in an increase in health service utilisation in the short term with the incentive value of the transferred cash diminishing over time. This might explain the observation in the TASAF programme in Tanzania, where a significant increase in clinic visits was seen at 1.5 years after initiation, which disappeared afterwards (30). The same was observed in the PROGRESA programme, where the impact of the programme on preventive health service utilisation was not significant after 8 months (2).

This review is the first to report no positive impact of CCTs on health of children in sub-Saharan Africa. The evidence from other parts of the world has been mixed but overall positive. Findings from PROGRESA in Mexico and Familias en Acción in Colombia both show that child beneficiaries were less likely to report illness $(1,2)$. One possible reason for this difference in observed impact may be due to weaker health systems in subSaharan Africa. Also, the conditions were considered "soft" in many programmes in Africa, meaning there were no penalties for not meeting programme requirements. 
TABLE 6 | Effect of CCT on immunisation rates.

\begin{tabular}{|c|c|c|c|c|c|c|}
\hline References & Study design & Age & Outcome & $\begin{array}{l}\text { Baseline } \\
\text { (CCT) }\end{array}$ & $\begin{array}{l}\text { Baseline } \\
\text { (control) }\end{array}$ & Effect size \\
\hline Robertson et al. (23) & Cluster randomised design & 0-59 months & $\begin{array}{l}\text { Complete immunisation } \\
\text { records (\%) }\end{array}$ & 66.0 & 66.0 & $\begin{array}{l}1.9 \%(95 \% \\
\mathrm{Cl}-4.9,8.8)^{\mathrm{a}}\end{array}$ \\
\hline Adubra et al. (26) & Cluster randomised design & 12-42 months & $\begin{array}{l}\text { Complete immunisation } \\
\text { records (\%) }\end{array}$ & 82.6 & 80.1 & $\begin{array}{l}1.32 \text { (95\% Cl 0.71, } \\
2.48)^{\mathrm{b} /}\end{array}$ \\
\hline Okoli et al. (28) & Cluster randomised design & 0-6 weeks & $\begin{array}{l}\text { Infants vaccinated per } \\
100,000 \text { population }\end{array}$ & Not reported & Not reported & $1.15(p=0.92)^{c €}$ \\
\hline
\end{tabular}

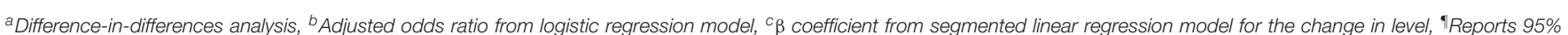
confidence interval, ${ }^{€}$ Reports p-values, Cl, confidence interval.

TABLE 7 | Effect of CCT on health status as measured by illness report.

\begin{tabular}{|c|c|c|c|c|c|c|}
\hline References & Study Design & Age (months) & Outcome & $\begin{array}{l}\text { Baseline } \\
\text { (CCT) }\end{array}$ & $\begin{array}{l}\text { Baseline } \\
\text { (control) }\end{array}$ & $\begin{array}{l}\text { Effect size } \\
\text { (p-value or } 95 \% \\
\text { Cl) }\end{array}$ \\
\hline Bliss et al. (25) & Quasi-Experimental design & $6-24$ & $\begin{array}{l}\text { Mean number of preventive } \\
\text { health visits in past year }\end{array}$ & 99 & 91 & $+7(0.17)^{\mathrm{a}}$ \\
\hline Adubra et al. (26) & Cluster randomised design & $12-42$ & $\begin{array}{l}\text { Reported ill in the past } 15 \\
\text { days (\%) }\end{array}$ & 19.9 & 23.0 & $1.02(0.58,1.08)^{\mathrm{b} q}$ \\
\hline \multirow[t]{2}{*}{$\begin{array}{l}\text { Evans and Hausladen } \\
\text { (30) }\end{array}$} & Cluster randomised design & $0-59$ & $\begin{array}{l}\text { Reported ill in the past } 4 \\
\text { weeks (\%) }\end{array}$ & \multicolumn{2}{|c|}{75 (combined) } & $-0.10(>0.1)^{c}$ \\
\hline & & & $\begin{array}{l}\text { Number of sick days in past } \\
4 \text { weeks }\end{array}$ & \multicolumn{2}{|c|}{1.05 (combined) } & $\begin{array}{l}-0.70(0.1>p> \\
0.05)^{\mathrm{c}}\end{array}$ \\
\hline
\end{tabular}

${ }^{a}$ Difference-in-differences, ${ }^{b}$ Adjusted odds ratio from logistic regression, ${ }^{c} \beta$ coefficient from linear regression, ${ }^{\text {II Presents }} 95 \%$ confidence interval, Cl, confidence interval.

\section{Strengths and Limitations of the Review Strengths}

This review combines information from multiple sources, across studies and between disciplines, in an attempt to synthesise the evidence about the impact of CCTs in sub-Saharan Africa. To our knowledge, this is one of the first reviews that has focused solely on this region. One important strength of the review lies in the application of a programme impact pathway to guide the review process, which allows for a more in-depth assessment of the impact of CCT. Also, checking for evidence along pathways allowed us to assess causal linkages between components of the intervention, intermediate outcomes, and overall health outcomes.

\section{Methodological Limitations of the Included Studies}

An important limitation arises from the internal validity of the included records. As reported in the results section of this review, all the quantitative reports had at least one major quality concern. The nature of the intervention makes blinding of beneficiaries impossible; therefore, response bias is a concern in all evaluations of CCT. Blinding of outcome assessors where possible could mitigate the risk of observer bias; this however was not implemented in any of the studies. Observer bias may result in an overestimation of the positive impact of the intervention. However, it is also possible that beneficiaries reported worse outcomes in the hopes that they will receive larger cash benefits. The latter possibility could result in a bias toward finding no impact of CCTs among beneficiaries.
The risk of confounding in most of the included studies was limited as they applied randomisation. However, two studies used a quasi-experimental design which is vulnerable for confounding. None of the reports on cluster randomised studies provided adequate justification for sample size estimation. Also, no justification was given for the number of clusters included in the cluster randomised studies. Finally, some evaluations made multiple comparisons. This can lead to the so-called multiple comparison problem, where spurious associations are identified purely by chance.

\section{Limitations of the Review}

Other potential limitations of this review include bias due to selective publication and/or differential outcome reporting (reporting bias). Our search strategy was extensive and included grey literature-inclusion of grey literature is expected to reduce reporting and publication bias. On the other hand, most of the grey literature we identified originated from the websites of organisations that are engaged in CCT implementation. These records may, therefore, over-report findings of positive impact. We were unable to formally assess the risk of publication bias with a funnel plot due to the small number, and the large diversity of studies reporting on each outcome (35).

The review would have benefitted from a meta-analysis to produce pooled estimates of effect. However, this was deemed inappropriate in this review due to the observed variability in 
the included studies. The study designs, context, design of the conditional cash transfer programme and outcome measurement differed between the included studies.

\section{Interpretation of the Findings}

There are multiple possible explanations for the inconclusive evidence around CCT and child health; these may include programme design and implementation fidelity, contextual factors and potential unwanted effects. Very importantly, CCTs likely address only a limited number of the myriad of interlinked factors driving poor child health (37). It is therefore probable, that even in the presence of robust and well-implemented CCT programmes, other factors may undermine the impact. Although many of the intervening determinants of health are influenced by socioeconomic factors $(37,38)$, it is unlikely that CCT programmes have an impact on the short-term socioeconomic status of household, and long-term socioeconomic benefits have not been established.

In many of the studies in this review, the conditions required for cash transfers were not strictly imposed (described as soft conditions). The soft nature of the conditions could explain why an increase in routine clinic attendance was not observed in some programmes despite this being a requirement for cash transfers $(26,30)$. Secondly, inefficient targeting may result in the programme missing out on the most vulnerable children within the community. Ineffective targeting may also be lead to a reduction in overall effect of CCT programmes.

Many of the rural populations in SSA where CCTs have been implemented experience multi-dimensional barriers to essential health services. The size and nature of these barriers may influence the impact of CCT, with greater impact where financial constraints are responsible for poor uptake (1). Conversely, where cultural and religious beliefs result in poor health services utilisation, conditional financial incentives may be ineffective. Furthermore, most of the reviewed CCTs were implemented in countries with poor health system indicators-e.g., measured by health worker density (Supplementary Table 1). In these cases, much of the poor access is driven by supply-side constraints and CCTs are unlikely to address health access problems. Indeed, some experts suggests that supply-side intervention, including healthsystem improvements, are required for the success of any CCT programme (1).

Unwanted effects have been reported in relation to CCTs, and these effects may limit impact on beneficiaries or have a detrimental effect on non-beneficiaries. While unwanted effects were not discussed in any of the programmes included in this review, they remain a possibility. For instance, CCTs have been known to result in an increase in food prices in communities (39). This may have constrained the impact of the intervention on childhood nutrition or even led to poorer nutrition in non-beneficiaries. As a final point, it is possible that the extra income may have been used for other household purposes. For instance, there was reported increased spending on clothing for adult females in household who benefited from the TASAF CCT programme.

\section{CONCLUSION AND RECOMMENDATIONS}

This review highlights the paucity of rigorous studies reporting on the impact of CCTs on child health and health service utilisation in sub-Sahara Africa. There is inconclusive evidence that these interventions improve access to health services for children in sub-Saharan Africa. These findings contrast with evidence from other regions of the world where impact on health status and access to health services has been more positive.

\section{Implications for Practise}

Several important considerations became apparent during the conduct of this review, which should inform future implementation of CCTs within SSA. Firstly, it is important that the design of CCTs-and indeed any type of intervention aimed at improving health access-is based on sound understanding of the context-specific drivers of poor health access (demand vs. supply constraint). Where the supply of health services is poor (no availability), interventions like CCTs that aim to improve demand are unlikely to have significant impact.

Due consideration should be given to the amount of cash that is likely to have a positive incentive effect on recipients. We see that most of the CCT programmes with small cash transfer did not have a positive effect on health service use. This then raises the important consideration of the cost of these programmes and their sustainability. Evidence suggests that CCT programmes are associated with large administrative costs related to targeting and monitoring of participant's compliance to conditions. This high running cost may make these interventions unsustainable in the long term (1).

Furthermore, in the design of CCTs targeting children, it appears that certain components, such as food fortification, and health and nutrition education are particularly relevant. It is therefore important that these components are considered in any such interventions aimed at improving nutrition and health of children.

Finally, the conditional cash transfers have been criticised for imposing conditions on cash transfers, infringing on individual freedoms and decision-making capacity, as well as enshrining structural power imbalance (within communities and between provider and beneficiaries) (40). Some authors have cited the burden on beneficiaries, unpredictable attainability of the conditions, receptiveness of beneficiaries, and the potential for negative effect as potential problems with CCT programmes (41). For instance, beneficiaries of CCT may not be able to meet conditions due to wider contextual factors, such as distance to facility, poor roads, or even a health system that is not patient-centred. This further underlies the importance of a context-specific approach in designing CCT programmes. Significant background knowledge of the local context is required in the design of ethical CCT programmes. 


\section{Implications for Future Research}

The first area for further research involves trying to understand the influence of contextual factors on the impact of CCTs. The current published studies are inadequate in achieving a full understanding of how, where and for whom CCT programs have benefits. A theory-driven rather than methoddriven approach is necessary, especially one that situates the programmes within a wider system and environment. This is particularly relevant for interventions designed to address complex problems (39).

A second future research area is to separate and understand the different components of the CCT strategy. Gaps remain in the literature on the mechanisms by which these interventions work, the pathways by which they work and the influence of context. This will require the development of detailed programme impact frameworks based on sound theory. These frameworks will help in the design of evaluations that could be better suited to explain the key components of the CCT strategy. CCTs by definition are complex and therefore any evaluation of their impact should take into consideration this complexity (40).

There is also the need to compare the impact of CCTs with other service delivery interventions on improving health access for children. This will hopefully help inform policy choices on the most effective approach to improving child health and access to health services. In addition, the cost of these interventions needs to be carefully documented and evaluated to help guide policy decisions.

\section{REFERENCES}

1. Lagarde M, Haines A, Palmer N. The impact of conditional cash transfers on health outcomes and use of health services in low and middle income countries. Cochrane Database Syst Rev. (2009) 2009:CD008137. doi: 10.1002/14651858.CD008137

2. Leroy JL, Ruel M, Verhofstadt E. The impact of conditional cash transfer programmes on child nutrition: a review of evidence using a programme theory framework. J Dev Eff. (2009) 1:103-29. doi: 10.1080/19439340902924043

3. Levy J, Ohls J. Evaluation of Jamaica's PATH Program: Final Report (2007).

4. Kandpal E, Alderman H, Friedman J, Filmer D, Onishi J, Avalos J. A conditional cash transfer program in the philippines reduces severe stunting. J Nutr. (2016) 146:1793-800. doi: 10.3945/jn.116.233684

5. Raghunathan K, Chakrabarti S, Avula R, Kim SS. Can conditional cash transfers improve the uptake of nutrition interventions and household food security? Evidence from Odisha's Mamata scheme. PLoS ONE. (2017) 12:119. doi: 10.1371/journal.pone.0188952

6. Hoddinott J, Skoufias E, Washburn R. The impact of PROGRESA on consumption: a final report. Int Food Policy Res Inst. (2000) 1-31.

7. Attanasio $\mathrm{O}$, Battistin E, Fitzsimons E, Mesnard A, Vera-Hernández M. How effective are conditional cash transfers? Evid Colombia. (2005). doi: 10.1920/bn.ifs.2005.0054

8. De Bem Lignani J, Sichieri R, Burlandy L, Salles-Costa R. Changes in food consumption among the Programa Bolsa Família participant families in Brazil. Public Health Nutr. (2010) 14:785-92. doi: 10.1017/S136898001000279X

9. Maluccio JA, Flores R. Impact evaluation of a conditional cash transfer program: The Nicaraguan Red de Protección Social. Res Rep Int Food Policy Res Inst. (2005) 1-66.

\section{DATA AVAILABILITY STATEMENT}

The original contributions presented in the study are included in the article/Supplementary Material, further inquiries can be directed to the corresponding author/s.

\section{AUTHOR CONTRIBUTIONS}

$\mathrm{CO}$ contributed to conceptualisation, literature search, study selection, quality assessment of eligible studies, analysis/synthesis, and writing of initial manuscript. KV and $\mathrm{BM}$ contributed to conceptualisation, study selection, analysis/synthesis, and review of manuscript. All authors contributed to the article and approved the submitted version.

\section{FUNDING}

The review was conducted as Master thesis by $\mathrm{CO}$, under the supervision of $\mathrm{KV}$ and $\mathrm{BM}$. At the time of completion $\mathrm{CO}$ was supported by a scholarship grant from the Institute of Tropical Medicine-Director General of Development (ITM-DGD) from the Belgian government.

\section{SUPPLEMENTARY MATERIAL}

The Supplementary Material for this article can be found online at: https://www.frontiersin.org/articles/10.3389/fpubh. 2021.643621/full\#supplementary-material

10. Paes-Sousa R, Santos LMP, Miazaki ÉS. Efectos de un programa de transferencia condicional en efectivo en la nutricion infantil en Brasil. Bull World Health Organ. (2011) 89:496-503. doi: 10.2471/BLT.10.084202

11. Morris SS, Flores R, Olinto P, Medina JM. Monetary incentives in primary health care and effects on use and coverage of preventive health care interventions in rural Honduras: cluster randomised trial. Lancet. (2004) 364:2030-7. doi: 10.1016/S0140-6736(04)17515-6

12. Shei A, Costa F, Reis MG, Ko AI. The impact of Brazil's Bolsa Família conditional cash transfer program on children's health care utilization and health outcomes. BMC Int Health Hum Rights. (2014) 14:19. doi: 10.1186/1472-698X-14-10

13. Levy D, Ohls J. Evaluation of Jamaica's PATH conditional cash transfer programme. J Dev Eff. (2010) 2:421-41. doi: 10.1080/19439342.2010. 519783

14. Gertler P. International Food Policy Final Report the Impact of Progesa on Health (2000).

15. Gertler P. Do conditional cash transfers improve child health? Evidence from PROGRESA's control randomized experiment. Am Econ Rev. (2004) 94:336-41. doi: 10.1257/0002828041302109

16. Bassani DG, Arora P, Wazny K, Gaffey MF, Lenters L, Bhutta ZA. Financial incentives and coverage of child health interventions: a systematic review and meta-analysis. BMC Public Health. (2013) 13:S30. doi: 10.1186/1471-2458-13-S3-S30

17. Juan AR, Sotres-Alvarez D, Jean-Perre H, Teresa S, Salvador V. Impact of the Mexican program for education, health, and nutrition (Progresa) on rates of growth and anemia in infants and young children: a randomized effectiveness study. J Am Med Assoc. (2004) 291:2563-70. doi: 10.1001/jama.291.21.2563

18. de Groot R, Palermo T, Handa S, Ragno LP, Peterman A. Cash transfers and child nutrition: pathways and impacts. Dev Policy Rev. (2017) 35:62143. doi: $10.1111 /$ dpr.12255 
19. Campbell M, McKenzie JE, Sowden A, Katikireddi SV, Brennan SE, Ellis S, et al. Synthesis without meta-analysis (SWiM) in systematic reviews: reporting guideline. BMJ. (2020) 368:1-6. doi: 10.1136/bmj.16890

20. Liberati A, Altman DG, Tetzlaff J, Mulrow C, Gøtzsche PC, Ioannidis JPA, et al. The PRISMA statement for reporting systematic reviews and meta-analyses of studies that evaluate healthcare interventions: explanation and elaboration. PLOS Medicine. (2009) 6:e1000100. doi: 10.1371/journal.pmed.1000100

21. Booth A. Clear and present questions: formulating questions for evidence based practice. Library Hi Tech. (2006) 24:355-68. doi: 10.1108/07378830610692127

22. Sterne JAC, Savović J, Page MJ, Elbers RG, Blencowe NS, Boutron I, et al. RoB 2: a revised tool for assessing risk of bias in randomised trials. BMJ. (2019) 366:1-8. doi: 10.1136/bmj.14898

23. Robertson L, Mushati P, Eaton JW, Dumba L, Mavise G, Makoni J, et al. Effects of unconditional and conditional cash transfers on child health and development in Zimbabwe: a cluster-randomised trial. Lancet. (2013) 381:1283-92. doi: 10.1016/S0140-6736(12)62168-0

24. Vergnes JN, Marchal-Sixou C, Nabet C, Maret D, Hamel O. Ethics in systematic reviews. J Med Ethics. (2010) 36:7714. doi: 10.1136/jme.2010.039941

25. Bliss J, Golden K, Bourahla L, Stoltzfus R, Pelletier D. An emergency cash transfer program promotes weight gain and reduces acute malnutrition risk among children 6-24 months old during a food crisis in Niger. J Glob Health. (2018) 8:010410. doi: 10.7189/jogh.08.010410

26. Adubra L, Le Port A, Kameli Y, Fortin S, Mahamadou T, Ruel MT, et al. Conditional cash transfer and/or lipid-based nutrient supplement targeting the first $1000 \mathrm{~d}$ of life increased attendance at preventive care services but did not improve linear growth in young children in rural Mali: results of a cluster-randomized control. Am J Clin Nutr. (2019) 110:147690. doi: 10.1093/ajcn/nqz238

27. Le Port A, Zongrone A, Savy M, Fortin S, Kameli Y, Sessou E, et al. Program impact pathway analysis reveals implementation challenges that limited the incentive value of conditional cash transfers aimed at improving maternal and child health care use in Mali. Curr Dev Nutr. (2019) 3:113. doi: $10.1093 / \mathrm{cdn} / \mathrm{nzz} 084$

28. Okoli U, Morris L, Oshin A, Pate MA, Aigbe C, Muhammad A. Conditional cash transfer schemes in Nigeria: Potential gains for maternal and child health service uptake in a national pilot programme. BMC Pregnancy Childbirth. (2014) 14:1-13. doi: 10.1186/s12884-014-0408-9

29. Akresh R, de Walque D, Kazianga H. Alternative cash transfer delivery mechanisms: impacts on routine preventative health clinic visits in Burkina Faso. Natl Bur Econ Res. (2012). doi: 10.3386/w17785

30. Evans D, Hausladen S. Community-Based Conditional Cash Transfers in Tanzania. Washington: The World (2014).
31. Yotebieng M, Thirumurthy H, Moracco KE, Kawende B, Chalachala JL, Wenzi LK, et al. Conditional cash transfers and uptake of and retention in prevention of mother-to-child HIV transmission care: a randomised controlled trial. Lancet HIV. (2016) 3:e85-93. doi: 10.1016/S2352-3018(15)00247-7

32. Owusu-Addo E. Perceived impact of Ghana's conditional cash transfer on child health. Health Promot Int. (2016) 31:33-43. doi: 10.1093/heapro/dau069

33. Walsh D, Downe S. Appraising the quality of qualitative research. Midwifery. (2006) 22:108-19. doi: 10.1016/j.midw.2005.05.004

34. Evans DK, Holtemeyer B, Kosec K. Cash transfers and health: evidence from Tanzania. World Bank Econ Rev. (2019) 33:394-412. doi: 10.1093/wber/lhx001

35. Lau J, Ioannidis JPA, Terrin N, Schmid CH, Olkin I. The case of the misleading funnel plot. $\mathrm{Br}$ Med J. (2006) 333:597-600. doi: 10.1136/bmj.333.7 568.597

36. Lagarde M, Haines A, Palmer N. Conditional cash transfers for improving uptake of health interventions in low- and middle-income countries: a systematic review. JAMA. (2007) 298:1900-10. doi: 10.1001/jama.298.16.1900

37. Mosley WH, Chen LC. An analytical framework for the study of child survival in developing countries. Child Surviv Strateg Res. (1984) 2545. doi: $10.2307 / 2807954$

38. Whitehead M, Dahlgren G. What can be done about inequalities in health? Lancet. (1991) 338:1059-63. doi: 10.1016/0140-6736(91)91911-D

39. Filmer D, Friedman J, Kandpal E, Onishi J. Cash Transfers, Food Prices, and Nutrition Impacts on Nonbeneficiary Children. Policy Research Working Paper. Washington, DC: World Bank (2018). Available online at: https:// openknowledge.worldbank.org/handle/10986/29557

40. Scheel IB, Scheel AE, Fretheim A. The moral perils of conditional cash transfer programmes and their significance for policy: a metaethnography of the ethical debate. Health Policy Plann. (2020) 35:71834. doi: 10.1093/heapol/czaa014

41. Krubiner CB, Merritt MW. Which strings attached: ethical considerations for selecting appropriate conditionalities in conditional cash transfer programmes. J Med Ethics. (2017) 43:167-76. doi: 10.1136/medethics-2016-103386

Conflict of Interest: The authors declare that the research was conducted in the absence of any commercial or financial relationships that could be construed as a potential conflict of interest.

Copyright (c) 2021 Onwuchekwa, Verdonck and Marchal. This is an open-access article distributed under the terms of the Creative Commons Attribution License (CC BY). The use, distribution or reproduction in other forums is permitted, provided the original author(s) and the copyright owner(s) are credited and that the original publication in this journal is cited, in accordance with accepted academic practice. No use, distribution or reproduction is permitted which does not comply with these terms. 